\title{
People with Mental Disability in the Prospect of Communicative Anthropology
}

\author{
Hanna Żuraw \\ University of Maria Grzegorzewska, Poland
}

Copyright $\bigcirc 2017$ by authors, all rights reserved. Authors agree that this article remains permanently open access under the terms of the Creative Commons Attribution License 4.0 International License

\begin{abstract}
According to Ferdynand de Saussure's linguistic study and Mary Douglas's anthropological resolving I analyse - in perspective of anthropology of communication- social dialogue about people with mentally retardation and people with psychic diseases. Basic questions of my article are - "who, why, how, what" speak about people with these disfunctions. I present results of my research and I say - people like speak about freaks -they give us something inducing to thinking about another face of humanity.
\end{abstract}

Keywords Communicative Anthropology, Mental
Disability

\section{Introduction}

Anthropology is a field broadly understood as a description of ubiquitous human existence as far as homo sapiens emerged from community of human being until present-day society.

Anthropology provides description of mechanics of integration of societies or how they distance themselves from certain group and individuals. It describes permanence and changes of culture order. It exhibits the value of creation of framework in livehood or existence for disabled and non-disabled people through applying criteria of humanity evaluation. Getting it in anthropological facet allows to provide evidence against belief 'that is natural!' It just anthropology points that human being has in-born survival mechanism relatively little. The subsistence and remain being still alive for a long time, although we can say - for a short time - if we compare to dinosaurs' life time, mankind owes to something what is called culture. What is the culture? It is some kind of gained possession which is passed on successive generation.

However, just the culture is blamed for creation of disability, there is no way you deny its ubiquitous influence. It manifests itself even in the area of study on ideology at given stage of human life of the certain group. It deals with the genesis of division in societies.

In some area the separation of human life there is more obvious than in others. But as modern prophets say: they will increase 'irrespectively of official ideology of chances equalisation and apologising otherness' [1]. Keeping it on-going is derivative of life features, which constitute cultural order under circumstances of individualisation, competing and uniformisation (i.e. understood as banned to be different) [2]

It happens like that because in European culture 'yours' means still masculine human being, intellectual, finding science and progress valuable. He is characterized by moral self-control and familiarity with good manners, acquaintance, conventional bourgeois lifestyle. The way of his thinking and activity is characterized by self-control, rationalism, individualism, proper evaluation of beauty and order. And what is more he should be healthy and fit man [3]. Therefore who is 'the other'? He is like an allien - in opposition to presented vision of European man i.e. ideal man. 'The other' is characterised by controversial instinctive behaviour, features arousing contradictory feelings like fear, anxiety and on the contrary fascination. The 'allien' expresses his sexuality too much, with excessive emotion and his mentality or spirituality is primitive. It is associated with magic, animism and animal instinct [4]. He may earn admiration for his taboo abilities (hidden and protected) and also for his art, spirit and erotica. And on the contrary he brings feeling of fear due to be contradictory between omnipotent science, rationalism and his spiritual intuition. It shows different system of value, undermine status quo and elicit fear emotion of chaos in West culture. Exotic 'the other' threatens intellect, morality and order which is mollycoddled in the area of West Law [5]. In the past human race was barrier which may provide feeling of fear and give reluctance /sic historical typology Gobineau/. Nowadays various kind of disability arises different level of fear and social reaction.

This presentation actually shows prospect typical for anthropology. It focuses on socio-cultural mechanism and social reaction as a feedback in response to portray people of different behaviour. It is analysis under my own research of 
utterances of people from environment of disabled people and people with mental disability. I would like to draw special attention to commonality of discursive analysis of otherness in everyday life of ordinary people.

I present the way of evaluation and its criteria applied for needs of community. In this way I want to exam chances for integration of this society and normalisation of social livehood for mental disabled people. I would like to emphasize vitality of bond between local society and every inhabitant stigmatized by otherness. And I also portray some ways of copying with otherness in behaviour of mentally disabled and mentally ill people (sometimes people suffer from both of these stigma).

The value of anthropological facet is connected with anthropocentric approach, assuming vision of human being as entity of being type of homo eligens [6], mentally unrestrained creature with ability to be autonomous, self-reliant and independent in creation of meaning of facts, experience and phenomena. This approach allows researcher to learn something new and interesting in a given area from every member of this community. Researcher is a specific authority on custom and manners, competent evaluator. His private independent opinion is affected by creation of criteria of people evaluation and transferring their image. Third party appropriately according to their competence, motivation and systems of value build verbal communication, so that is their 'micro-world'. It works like word magic and motive power, due to the fact that language i.e. builder of reality is the kingdom of human being [7].

Suggested area of my research embraces study in semantics, semiotics, communicative anthropology, and broadly understood study on culture especially in the field of communication process and function of miscellaneous terms. It leads to question about alleged elimination of phenomena. If we do not name some processes in a scientific way or even colloquially, what will happen then? Disappeared? We ask about type of social reaction in case of frequent non-physical disability. He or she looks like typical person, but his or her behaviour seems to be a little strange. The special area of my interest was verbal and non-verbal behaviour of people with mild mental disability. Their life style and their image created in the area of common awareness are characterized by different kind of dichotomy. This dissonance is visible at miscellaneous stages of his or her life and situation. Being mentally disabled contradicts good assessment in humanity measurement of intellectual efficiency in meeting requirements imposed on perfect man of modern world. According to them he or she should be intellectually very efficient with huge capability in order to be independent in life, rational thinking, making decision, and adaptation to changes. Mentally disabled people may be considered as particularly weak and strange. Traditionally they are accused of inability to make good choice and proper assessment of situation and matter $[1,8,9,10]$.

Disability sometimes intrigues, sometimes raises a fear or fascination, but very rare people are unresponsive. Hence, there is a need to analyse this common discourse of 'otherness'. That anthropology just responds to this question.

\section{Miscellany of Anthropological Study on Disability}

The area of interest of anthropology is huge. It is multi-disciplinary broadly understood study on culture and humanity. It focuses on biological, cultural and social peculiarities [11]). However, anthropology has no aspirations to replace particular science in their information or analytical function and may bring comprehensive image which is difficult to create elsewhere. The genesis of holistic approach underlies specific all-encompassing view of original anthropological research, that concerned relatively little community and its short history [12]), called them 'communities without history'[11].

It allowed to do research almost multi-faceted. This style of doing research is typical for overall approach in anthropology contextualized in specific situation of human life.

Therefore anthropologist understands better overall connections, which are missed by specialists due to be beyond their area of interest [13] e.g. wide range of disability in society. It focuses on extensive connections between characteristic feature of people and their products. Ethno-methodologists consistently develop and justify conviction that all manner of objectivity in assessment of social facts is determined by situation achievements. Dualism object-subject is exceeded. Interpretation constitutes meanings of subject [14]). The selection of determined procedures and rules is not a choice of legible alternatives, but the act of building. Its legibility increases or decreases under its construction. In decision structure encompasses element of concealing legibility and justifying post factum.

Modern scientific anthropological thinking makes attempt to take up the step to ethnological analysis of human body as a specific kind of reading by people who belong to the same or different culture environment [15]). This way of thinking is connected with attribution special meaning to parts of human body and miscellaneous changes, deformation, diseases, congenital defects, etc. What is on the top or in the front or at the right, fair is more valuable than something at the bottom, on the left side, etc. What is worthy of our attention? Head and efficient brain. If this part of human body does not work properly due to e.g. improper behaviour, the human being is not treated as a rightful member of mankind.

Anthropological reflection on evaluation of results of disability reveals two faces of culture relativism:

- $\quad$ soft-relativism which treats dis-function as a partial limitation i.e. a hindrance to work and feel some kind of experience, e.g. feel sorry for somebody or something: 'It is a pity to be blind in the courtyard of 


\section{lions in Grenada'}

- hard-relativism which treats dis-function as a total limitation, syncretizing disability as ubiquitous phenomenon, concerning disabled person entirely.

One of the most basic question of anthropology is how various nations, tribes, or ethnic group perceive connections between disability and humanity and how biological dis-function affects peculiarity and how given culture perceive miscellany: as a part of human reality or part of non-human world? It refers to theory of symbolic marking. According to it disability is some kind of stigma, which decreases social status. Also social agencies perceive this problem in such a way, applying this diminishing model [16].

Anthropological reflection refers to casualties and their social function in the world of norms and manners of certain culture. Conceptualisation of criteria variety of humanity seems to be essential. These criteria are changeable in much culture, particularly in Euro-American culture. What is more they are subject to change in time according to science and medicine achievements and their evaluation.

E.g.in ancient culture in Europe mentally disabled were out of law. Due to be considered as possessed by an evil spirit, their parents had to pay the penalty. They were perceived as slaves. But in India 100 years ago mentally disabled (with microcephaly) lived in the temples. They were considered to be in a state of grace as good spirit of temple. Visitors fondly called them 'rats of king Daul'. In some parts of India mentally disabled are much respected due to religious matter and they are perceived as a god. Olmec people considered children with Down syndrome as distinguish as descendants of women and god-jaguar.

If disability is becoming increasingly commonplace, that will be the factor of acceptance. Sometimes illness was perceived as a norm, e.g.in the past in Switzerland in big communities suffering from cretinism /due to lack of iodine/ disabled people was considered as sinless people, blessed by God. According to Ryan and Thomas, that time family without mental disability fell out of God's favour. Brian Kirman suggested that they had high social status and they were described as 'les enfants du bon Dieu' [17].

The contrast between global orientation in particular societies is visible. In individually oriented countries like West Europe and the USA disability is graded according to scale of independency and chances to be self-reliant. In socio-centric environment you pay attention to capability to establish social contact. To be a member of society in order to meet requirements for your age and gender is more significant than ability to work and good appearance.

Anthropological deliberations put the question of non-material matter in bringing disease and disability. In Euro-American culture it is commonly believed that disability is accidental and biological defect. In various countries there are miscellaneous religious beliefs on contribution to given dis-function e.g. spell or a witch's curse, divine retribution $[18,19,20]$.

\subsection{Anthropology Analyses Link between Taboo and Human Health}

People look for the reason of disability often in taboo, e.g. sexual relations in illicit period of love affair [21]. It is questioned about illness and also why just that person suffers from it.

Anthropological study describes medical procedures in various countries and tribes. It is an accurate reflection of the state of medical knowledge and public mood. Lack of understanding of suffering affects behaviour of majority of non-disabled in all relationships, especially attitude towards mentally disabled. E.g. as early as Hippocrates knew autism and he classified it as "divine ailment" - serious and inexplicable disorder in behaviour. Due to the lack of understanding it was considered as an "insanity". In biblical times children were led to healers in order to change their behaviour through God's intervention. Healers attempted to drive out 'evil spirit' or to 'make him or her clear' in the hope that demon will be tamed and the child will be healthy. In ancient Greece and Rome such children and others who made some troubles were sewn up in billy-goat skin /capro, Italian word origin of the term 'capricious'/ in order to calm down the strange behaviour. The process of drying skin helped to immobilize the child as a straitjacket [22]. Hence, it is easy to notice that anthropology deals with medical problem as well as people who are involved in treatment or therapy of disabled. They are physicians, shamans, witch doctors, herbalists and sometimes sheiks [23, 19].

Anthropological reflections take into consideration who initiates activity for disabled - today scientists pay attention to specialists who earn money on disability and illness.[2].

Anthropology deals with influence such factors as gender, age and type of disability on people situation e.g. complicated situation of disabled women who are perceived as lees valuable than non-disabled; and also less competent, worse wives for non-disabled men. However, on the other hand society permits them to be illegal sexual partner [24, 25].

Anthropological academic achievement is pretty good. Therefore new scientific field was emerged from anthropology as sub-domains: physical anthropology, culture anthropology, social anthropology, communicative anthropology, psychological anthropology, philosophical anthropology, pedagogic anthropology. Every area of these studies is related to disability problem in specific characteristic way. As I said before, my presentation refers to communicative anthropology.

\section{Peculiarity of Communicative Anthropology}

Characteristic feature of anthropology is perceiving culture as signs system and a form of communication. Human being as a culture being is involved in 
communication process. He exists as a creator, addressee, and user of culture transmission. Communicative anthropology exams the way of construction and transformation of elements in communication process [26].The area of research concerns directional and non-directional signals and ways of transfer i.e. verbal and non-verbal transfer. /proxemics and kinesics [26]. This approach to culture as a signs and communication system contributes to take a new aim, i.e. decipher codes and interpretation of Szulc, [27]. In handbooks on communicative ethnography researcher draw special attention to four layers of contents concealed in verbal sphere and non-verbal domain: factual contents, emotional attitude towards yourself and interlocutor represents verbal sphere; but appeal, wishes and expectations is mostly hidden in non-verbal sphere. It resulted from need of a good information on context of this utterance in order to analyse it properly. Such understood anthropology is connected with ethno-methodology, ethno-linguistics, culture linguistics, socio linguistics, communicative ethnography, (studies on communication).

Inhere disability is identified with otherness which 'lives in word, but the word is fed by otherness'. Anthropologicalcommunicative study on disability is miscellaneous. Some of them go to the past.

It exams contents of various media and means in terms of the results of illness, congenital defects or after-effects of tragic accidents. Sometimes it may be analysis of ethno-historical material from the distant past, distant culture and custom, written in fairy-tales, myths, beliefs and folk medicine [22, 28, 29, 30, 31, 32, 33, 34, 35, 36].

Communicative anthropology pays attention to difficulty in world standarisation of the term 'disabled'. In official taxonomy, created by WHO is referred to biomedical terminology of disfunction and their diseases. However, eg.in Norway the criterion of efficiency is capacity to fulfill social function; sometimes omitting criterion of biomedical taxonomy, e.g. old age, immaturity, disgusting appearance, unknown origin, absent-mindedness. A lot of presented disabilities is social not biological. The analysis of terms used to describe deviation from an average measurement demonstrates difficulty in making terms world standard. In some countries there is out of the question, due to the use of terms drawn on popular beliefs and situation factors [31].

In verbal area there are a lot of paradoxes which create otherness and the use of these may even impede communication between people with different grade of disability. In Euro-American culture term 'disability' come out badly if it is used directly, e.g. if you tell blind, talking directly to disabled with visual impairment. It is made pretence of similarity or equality for disabled and non-disabled. It is emphasized necessity of integration in ordinary life style. Also disability is a subject to steer clear of. Such attitudes towards disability do not solve the problem. People with severe biological and mental impairment are not considered as human beings. Sometimes they are perceived as creatures with doubtful humanity, some kind of vegetables [37]. Ethnographical literature points that in social perception the most devaluating and made people inhuman seems to be serious congenital defects, revealed in early childhood when organism is not formed yet, e.g. children with serious congenital problem are expected to die [38]. Illness or congenital disorders establish symbolic borders between human and non-human, natural or supernatural, normal and abnormal. It is emphasized the 'ease', freedom and playfulness in determination of types of difference and the way of treatment.

Communicative anthropology also deals with legal system processes, i.e. how to establish place for disabled in social hierarchy by overlapping socio-techniques for disabled and non-disabled people. It is worthy of notice that specific geographical, biological and cultural circumstances are taken into consideration. [31]. In West-European countries disability is determined by law. Stiker argues that legislation process helped to make definitions, criteria and grades of disability in order to allow weakness to exist and achieve status that never been its contribution before [39]. Disabled people were given double identity: first - social; due to difficult, painful life, second as citizens with full rights. Nevertheless disabled are being under limitation/ Murphy/ in spite of the special industry for handicapped came into being, i.e. specialists for example if disabled apply for disability pension. Obviously in various countries there are different criteria in order to grant the pension, e.g. in the USA granted are people who suffer from permanent pain, in Scandinavia registered alcoholic.

Communicative anthropology pays special attention to taking up culture issues. To tell or not to tell about matters concerning body, paying attention to dis-function or avoiding inconvenient subject and what consequences disabled people have to face in their life.[40] Comparative studies in anthropology preceded historical overview allow to verify stereotypes of disabled people and their families who lives according to the nature. It is obvious that social integration and recovering from the detriment of own health is neither a possession of 20th century nor Euro-American culture. What is more we find out that exclusion is not evident issue and equal in everyday life on each level of social life. As long time ago it was said: 'village administrator wears big glasses, has a pension, seemingly money, but what is a farmer and a husband? A village administrator could be: possession, respect, but no woman. He had a girl, resourceful girl, but her parents denied him'. Well-known, but specific source of knowledge of custom and social processes are legends, e.g. 'About woman who wore a German helmet and garland on it ', or about people from a luxurious rest home 'people from marble house'. It is not expression of reluctance, but rather interest. There are not gossips, but rather fascination. 


\section{Forms of Reaction}

In anthropological study it is presupposed that sense and motor dis-function are in general present in history of life on Earth and commonplace. According to a given culture norms in force evaluation of disability, its grades, effect-cause is different. There is neither one kind of disability nor illness. Each case arouses specific reaction. Sometimes more clear, traditionally considered as illness e.g. blindness, cancer, motor dis-function, etc. Conventional diseases awaken compassion, superstition, fear or even magic thinking 'I don't want to think about it because I don't want to bring disaster on the whole village![41].

Others, like mental disability arouses less diverse reaction. The genesis of the diversity in reaction underlies in dichotomy in perception of this disability. Majority of disabled look like ordinary people and their behaviour is typical for majority. Some of their reactions are incomprehensible if we use culture sophisticated tools. Sometimes it is hard to say what would be better to laugh or to cry ... The criterion of evaluation is not a fracture of established norms by others, but uncertainty and helplessness of a viewer. The behaviour of mental disabled awakens feeling of ambivalence, stress and distance from non-disabled. Very often laugh seems to be a tool to relax and wind down conscious control in aid of oblivion. [26]. Comic relief in such situation presents elements of world view which are usually hidden. The way of thinking which is normally elusive and activity of 'fool' who sometimes could succeed is contradictory to commonly accepted models, making them useless. Nevertheless orderly experiences are arbitrary and subjective [26]. 'Foolish-man' sometimes wins. He manages to avoid punishment, succeeds being evidence that 'any fool has his wits'. He is not as fool as he's been thought. That's just an extraordinary case and perverse wisdom vel cleverness or stupidity become element of story about misfits [28]. Nowadays in countryside stories the main hero shouldn't be foolish, but ordinary inhabitant, country-man who does the wrong things. Hence, that 'misfit', 'bob', 'waif' is irritable [26], not alarming, disturbing, worrying due to its negative reference /as worse, making ashamed, ridiculous/ and simultaneously fascitinating [42]. It reveals people's superstitions, concealed conceptions and the most essential archetypical beliefs of humanity [8]. All the more so as Mary Douglas said: 'social environment of misfit is often made fool out. It is some kind of social auto-irony, expressed in various ways. Usually schematic behaviour is a subject to mock.[43]. Comic situation, however also more sophisticated satire based on unconventional behaviour leads to laugh, which is indication of being tamed. It is allowed to make fun at known misfits, unknown - arouses fear. A. Perzanowski [44] distinguishes a few types of misfits:

Triumphal misfit who is foolish, but right. Comic aspect illustrates cognitive problem caused by otherness. It suggests miscellaneous kinds of wisdom and illusory of simple classification: wise/stupid. Seemingly stupid is often wiser than wise.
The hero is presented in perverse and paradoxical way. He is clever or 'wise on his own way'. He is doubled characterized by triumph and fun.

Another kind of misfit is a clown. He needs space and viewers. The clown is placed in front of audience. Sanction of seriousness is imposed on him. He cheats when he plays the role since he must keep a straight face. He diverts audience's attention from the heart of the matter or problem and change the course of events and playing rules [26,45]. The point is otherness whereas misfit attempts to be serious but the audience seemingly tries to follow him. It determines good fun and authentic comic experience.

\subsection{Generality of Social Interest in Misfits}

There are some reasons of interest in misfits. Every member of community is interested in. Everybody knows something and may have your say and utter significant words. It is a prerequisite for coexistence and collaboration of community.

One of them is searching for information about people. The members of community due to even safety issue want to know who lives next-door. It also raises self-confidence and competence and self-evaluation. He knows how to wear, how to treat misfits. Everyone else is 'less competent'. You are an expert in this area. Talking about otherness as dangerous to others you deserve for respect as a person who takes care about safety in community. You become clever and witty commentator. Hence this discussion is very economic and profitable.

\section{Taming of the 'Misfit'}

Discussion on 'other' at local community level is significant and results in practice. It leads to tame and allocate him in community without necessity of medical therapy, psychotherapy or technology. In other words the community copes with others. As result of this managing others sometimes arouse compassion, laugh or even fear induced by 'alien' from outside the community. The alien is tamed, and people learn how to treat him with special symmetrical rules. Traditional procedures are unreliable inhere. Otherness requires special treatment because 'stupid cannot be treated normally'. The reasons of it is explained outwardly 'in natural way' as traumatic experience beyond science. Tamed misfits are better understandable and their behaviour is not a fringe issue. They are treated individually according to their features and abilities as 'Kosmalka was a normal person. She had a husband. She was working, but she was not familiar with money" /footnote of it. author/. When these needs are recognized competent disabled with optimistic prognosis will be allowed to have a partner and job [46].

Also 'internal alien' assessed as troublesome are not alone. They are protected in community, under cloak of help. 
Protectors promote superstition on honest world: 'you should help otherwise you will be out of luck!'[47]

\subsection{Everything is Perceived as a Sign and Has Meaning as a Symbol. Some Scenes of Misfits' Life in Everyday Narration of the Viewers}

Communicative anthropology gives a lot of information on life style of the people who are considered as misfits. They always arouse interest. Information come from ordinary people and it is based on stories about everyday life of people who considered mental disabled as misfits. The inquiring process is meticulous, referring to features of situation of entity and evaluation her competence. Below there are some examples of descriptions. They point out that society analyses:

- reason of dis-function (traumatic childhood, without mother care or she was married off to get rid of her from home

- everyday life with misfit. Usually shows some troublesome "dark" side of this life due to different behaviour of the misfit. He is a source of fun, but also irritation, stress and fright e.g. 'his dread of something, i.e. he has been crying for the whole night since his childhood or he has always run away from rest home' or he pestered parents to do what he wanted to.

- mimic behaviour': he looked like a zombie and he frightened people with his face',

- pantomime 'Teddy-bear'/nickname of inhabitant of nursing home / He has always climbed onto a tree and he was sitting there for long hours',

- competence-e.g. knowledge of rituals, customs.-"she could not throw a party'

- wealthy level - sometimes emerges new criteria of poverty. They had not any computer /own footnote/,

- love affair and sexual behaviour e.g. 'there was not any rendez-vous, they went away, went to bed and they had child' or 'they met at school for disabled and they had 12 children, all of them handicapped you can't stand them watching it'

- ways of thinking, 'he was quite normal. He had wife and children, but he preferred little girls'.

- delight 'he loves to scour pots and sometimes he lived in coop'

- attributes "that who carries plastic rifle,

- ways and contents of information: 'That is he who regardless of her beauty, told every woman how pretty you are today!'

- clothes and own decorations 'Everyday she wore German helmet with flowers on it and nightgown and when she was told to wear casual clothing she was angry and shouted'.

- $\quad$ specific of verbal and non-verbal behaviour.

Research shows contradictory between commensurate activity with situation context, e.g. he shouted in church' or 'he wore women's clothes in office'. One of criterion of assessment is economically justified verification of obeying rules. Misfit or incompetent does not obey these rules. Also the way of thinking is criterion of being stiff or numb.

- names' diminutive, e.g. in order to give status of perpetual kid, e.g. 'our children' in spite of these children are adults, for adult man - little Timmy', etc.

- $\quad$ space, i.e. enough room for public activity and privacy (house, appearance, etc.). Overlapping of these areas contributes to introduction of elements of magic and intimacy, atmosphere of mystery which is typical for disabled. It is considered as lack of competence-'he got undressed and on a bus and he was stripped naked at the bus stop'. Misfits often do not have permanent address i.e. place of residence. Sometimes at nursing home they are called 'kites'. They looked for opportunity to escape from nursing home then went and spent nights on the mountain. /footnote it. author/.

The basement of being recognized as 'your man or woman' is: - basic attributes of grown-up man or grown-up woman, i.e. healthy partner, children, job, income, own house or apartment. On the contrary umarried, childless, jobless, homeless are classified as 'social children' in order to be subject of preferential treatment as not fully adults. Also job ability is essential. Baby-sitting skills are additional advantages. What is vital? Good will and respect for work. Job ability is always recognized in spite of otherness (e.g. 'he doesn't work because he tilts at windmills' (to fight a losing battle) /after Perzanowski/. Doing something non-profitable reduces social status.

\section{REFERENCES}

[1] Bauman Z. (2003). Życie na przemiat, Warszawa, PWN

[2] .Barnes C., Mercer G. (2008). Niepetnosprawność, Warszawa, Wyd. Sic!

[3] Heathertorn T., Kleck R., Hebl M., Hull J.(2008). Spoteczna psychologia piętna, Warszawa PWN

[4] Fanon F. (2008) Black Skin, White Masks. Get political Liberation classics, Grove Press

[5] Sztompka P., Bogunia -Borowska M. (2008). Socjologia codzienności, Kraków, Wydawnictwo "Znak",

[6] Siciński A. (1988). Style życia w miastach Polskich u progu kryzysu, Warszawa, PWN

[7] Folkierska A. (1990). Pytanie o pedagogike, Warszawa, Wyd. UW

[8] Gobineau J.A. (1856).The Moral and Intellectual Diversity of Races, with Particular Reference to Their Respective Influence in the Civil and Political History of Mankind, Philadelphia, PA, Lippincott;

[9] Benedyktynowicz Z. (2000). Portrety “obcego'. Od stereotypu do symbolu, Kraków, Wyd. UJ. 
[10] Firkowska - Mankiewicz A. (1999). Zdolnym być...Kariery i sukces życiowy warszawskich trzydziestolatków, Warszawa, Wyd. IFiS PAN.

[11] Nowicka E. (1997). Świat człowieka - świat kultury, Warszawa, PWN.

[12] Levi-Strauss C. Antropologia strukturalna, wyd. I: 1970, wyd. II: Warszawa 2000, Wydawnictwo KR, (Anthropologie structurale 1958).

[13] Korporowicz L. (1996). Tworzenie sensu, Kraków, Wyd. Uniwersytetu Jagiellońskiego, Kraków.

[14] Paluch A. (1995). Etnologiczny atlas ciała ludzkiego i chorób, Wrocław,Wyd. Uniwersytetu Wrocławskiego.

[15] Siemaszko A. (1993). Granice tolerancji. Teorie zachowań dewiacyjnych, Warszawa, PWN.

[16] Baranowski B. (1981). W kręgu upiorów i wilkołaków, Łódź, Wyd. Łódzkie.

[17] Stradford B. (1993). Zespół Downa, przeszłość, teraźniejszość i przyszłość, Warszawa, PZWL.

[18] Chodkowska M. (1993). Kobieta niepetnosprawna. Psycho-socjo-pedagogiczne studium postaw, Lublin, Wyd. UMCS.

[19] Talle A.(1994) A Child in a Child:Disability and Eqality among the Kenya Maasai, In: Instad and Whyte : Culture and...

[20] Wright B.(1967). Psychologiczne aspekty fizycznego inwalidztwa, Warszawa, PZWL.

[21] Devlieger P. (2011) Handicap et societe africaine culture et pratiques, L'HARMATTAN ISBN-10: 2296555489, ISBN-13: 978-2296555488.

[22] Frazier J.G.(1962). Zlota gałaź, Warszawa, PIW.

[23] Helander B. (1990). Mercy or rehabilitation? Culture and prospects for disabled in Southern Somalia in: Disability in a Cross-Cultural Perspective, Ed.Bruun F.: Ingstad B., Working Paper no 4 Oslo; Department of Social Anthropology, University of Oslo.

[24] Fassins D.(1994): Handicaps physiques, practiques economiques et strategies matrimoniales au Senegal. In Social Science and Medicine 32 /3/:267-272; Sentumbwe N. (1994) Sighted Lovers and Blind Husbands in Instad and Whyte: Culture and..

[25] Sentumbwe N. (1994) Sighted Lovers and Blind Husbands in Instad and Whyte: Culture and..

[26] Douglas M : Purity and Danger .An analysis of Concept of Pollution and Taboo, New York, Praeger /wyd.polskie: Czystość i zmaza/, Warszawa 2007 ,PIW ,thumaczenie Beata Biały
[27] Szulc R. (1996). Antropologiczne podstawy wychowania, Warszawa, Wyd. Akademickie “Żak”, Warszawa.

[28] Baranowski B. (1981). W kręgu upiorów i wilkołaków, Łódź, Wyd. Łódzkie.

[29] Brodniak W.A.(2000). Choroba psychiczna w świadomości społecznej, Warszawa, Oficyna Naukowa.

[30] Imieliński K. (1980). Seksuologia, Warszawa, PWN.

[31] Ingstad B., Whyte M., (1994). Culture and Disability, Los Angeles, University of California, Berkeley.

[32] Sournia A. (1998). Historia epidemii, Warszaw, Nowa Marianna.

[33] Swienko H. (1982) Magia w życiu człowieka, Warszawa,PIW

[34] Szumowski Wł. (1958). Historia medycyny, Warszawa, PZWL.

[35] Vigarello G. (1998). Historia choroby, Warszawa, Nowa Marianna.

[36] Zaleski G. (1994). Psychologiczna analiza obłędu, Białystok, Wydawnictwo Uniwersyteckie.

[37] Carling F. (1962). And Yet We Are Human, London, Chatto and Windus.

[38] Scheper - Hughes N. (1992). Death without Weeping: The Violence of Everyday Life in Brazil, Berkeley, Los Angeles, University of California Press; Baranowski B. (1981). W kręgu upiorów $i$ wilkołaków, Łódź, Wyd. Łódzkie.

[39] Sticer H.J. (1982). Corps infirmes et societes, Paris, Aubier Montaigne.

[40] Asch A.,Fine M. (1988). Women with Disabilities, Philadelphia Temple University Press.

[41] Swienko H. (1982) Magia w życiu człowieka, Warszawa, PIW.

[42] Żuraw H. (1998). Obraz osoby upośledzonej umystowo $w$ pogladach osób petnosprawnych, in Psychologia Wychowawcza nr 4/1998.

[43] Bergson H.(1995). Esej o śmiechu, Warszawa.

[44] Perzanowski A. (2009). Odmieńcy. Antropologiczne studium dewiacji, Warszawa,Wyd. DiG.

[45] Huizinga J.(1985) Homo ludens. Zabawa jako źródto kultury, Warszawa.

[46] Modrzewski J. (2004). Socjalizacja i uczestnictwo społeczne. Studium socjopedagogiczne, Poznań, Wyd. Naukowe UAM.

[47] Wojciszke B. (2002). Człowiek wśród ludzi, Warszawa, Wyd. Naukowe Scholar. 